\title{
Ultrastructure and Invertase Secretion of the Slime Mutant of Neurospora crassa
}

\author{
By CYNTHIA H. BIGGER, MARSHA R. WHITE \\ AND H. D. BRAYMER \\ Department of Microbiology, Louisiana State University, Baton Rouge, \\ Lousiana, 70803 , U.S.A. \\ (Accepted for publication I8 January 1972)
}

\begin{abstract}
SUMMARY
Electron micrographs of thin sections of cells of the slime mutant of Neurospora crassa showed that it, like artificially prepared protoplasts, possessed no cell wall. Invertase was produced by the mutant and appeared to be serologically identical to wild-type $N$. crassa invertase. The mutant secreted over $95 \%$ of the invertase into the medium whereas cells of the wild-type retained almost all the invertase. The slime mutant hence resembles wild-type protoplasts in both structure and invertase secretion.
\end{abstract}

\section{INTRODUCTION}

Invertase ( $\beta$-D-fructofuranoside fructohydrolase, EC. 3.2 . I .26) of Neurospora crassa, like many other microbial enzymes involved in carbohydrate catabolism, is found outside the cell boundary. The passage of macromolecules through the cell boundary and the localization of the enzyme molecules on the cell periphery require further study. Metzenberg (1963) demonstrated that $N$. crassa invertase is bound to the cell in a position external to the plasma membrane, and suggested that it is localized in the intramural space between cell wall and membrane. Sargent \& Woodward (1969) and Chung \& Trevithick (1970) found that 20 to $30 \%$ of the invertase associated with the $N$. crassa cell is bound to the wall. Meachum \& Braymer (1969) showed that $N$. crassa invertase can be released from the cell wall by treatment with chitinase. It is not known whether the enzyme is chemically bound to the wall or mechanically trapped within the chitin matrix. In addition to cell-bound invertase, actively secreted invertase is found in the medium (Trevithick \& Metzenberg, 1966; Sargent \& Woodward, 1969). The latter workers suggested that invertase molecules passed into the medium through pores (Manocha \& Colvin, 1967) in the cell wall.

Thus it was of interest to study invertase production in a wall-less mutant. The slime mutant described by Emerson (1963) seemed suitable for such an investigation; he reported that the slime mutant was devoid of cell wall visible under phase-contrast microscopy. However, Woodward \& Woodward (I968) indicated that the mutant contained a wall-like material which was shed to form a sphaeroplast. Hence it was essential to determine by electron microscopy whether a wall was present.

\section{METHODS}

Neurospora crassa strains. The slime, sl, strain I I 8 (Fungal Genetics Stock Center designation) and wild-type strain SF 26 (Gratzner \& Sheehan, 1969) were used except where otherwise stated. Wild-type strain $74 \mathrm{~A}$ was also used in the studies of invertase secretion.

Growth conditions. The medium for slime cultures was that recommended by Woodward 
\& Woodward (1968) and consisted of Vogel's citrate minimal salts solution (I964), $0.75 \%$ nutrient broth, $0.75 \%$ yeast extract, $2 \%$ mannitol and $2 \%$ sucrose. In addition, solid media contained $\mathrm{I} \cdot 5 \%$ agar but did not contain sucrose. The medium used for wild-type strains of Neurospora consisted of Vogel's citrate minimal salts solution supplemented with $2 \%$ sucrose.

Liquid cultures of slime organisms were usually inoculated with a loopful of material from a culture on solid medium. When standardization of the inoculum was necessary, growth from slants was suspended in $4 \%$ mannitol and equal amounts of this suspension were transferred aseptically to each flask. Volumes of $50 \mathrm{ml}$ were used in $250 \mathrm{ml}$ Erlenmeyer flasks and the cultures were incubated at $30^{\circ} \mathrm{C}$ on a rotary shaker at $200 \mathrm{rev} . / \mathrm{min}$. Slime cultures were grown on agar slants at $34^{\circ} \mathrm{C}$.

Electron microscopy. Liquid slime cultures were centrifuged after 24, 36, 48, 60, 72 and $96 \mathrm{~h}$ of incubation. Growth in solid medium was collected after 24,48 and $72 \mathrm{~h}$ of incubation by suspension in $5 \%$ sucrose followed by centrifugation. Fixation was begun by resuspension of the pellet in $3 \%$ glutaraldehyde in $0.1 \mathrm{M}$-sodium phosphate buffer, $\mathrm{pH} 7 \cdot 3$, containing $0.005 \% \mathrm{CaCl}_{2}$ with $10 \%$ sucrose to prevent osmotic rupture of the cells. The cells remained in this solution for 2 to $4 \mathrm{~h}$ at $0^{\circ} \mathrm{C}$, were transferred to phosphate buffer with $10 \%$ sucrose, stored overnight at $4{ }^{\circ} \mathrm{C}$, and fixed in I \% osmium tetroxide in phosphate buffer with $10 \%$ sucrose for $\mathrm{I} \cdot 5$ to $2 \mathrm{~h}$ at $0{ }^{\circ} \mathrm{C}$. After centrifugation, the pellet was mixed with molten $3 \%$ agar containing $0.5 \mathrm{M}$-sucrose and the agar cut into small cubes. Dehydration was carried out by passage of the cubes through a graded series of ethanol concentrations. The cubes were maintained in propylene oxide before embedding in Maraglas (Polysciences Incorporated, Rydall, Pennsylvania, U.S.A.). The wild-type strain was treated similarly except that sucrose was not included in the solutions.

Thin sections showing silver to silver-grey interference colours were obtained with an LKB ultramicrotome using a Dupont diamond knife and were placed on Parlodion (Mallinckrodt Chemical Works, St. Louis, Missouri, U.S.A.) coated copper grids. Sections were stained for I to $2 \mathrm{~min}$ with I \% uranyl acetate in $90 \%$ ethanol followed by $5 \mathrm{~min}$ with lead citrate (Reynolds, 1963). Examination and photography were done with an RCA electron microscope, model EMU 3-G, operated at $50 \mathrm{kv}$.

Invertase assays. The invertase assay was that of Meachum, Colvin \& Braymer (1971). Protein concentration was determined by the method of Lowry, Rosebrough, Farr \& Randall (I95I). Enzyme assay conditions utilized were those where first order kinetics prevailed. Specific activity of invertase was expressed as $\mu \mathrm{mol}$ of sucrose hydrolysed per minute per $\mathrm{mg}$ of protein. Total activity was expressed as $\mu \mathrm{mol}$ of sucrose hydrolysed per minute.

Secretion of invertase by slime was estimated by assaying the growth and the medium of 48,72 and $96 \mathrm{~h}$ cultures. Enzyme secretion by wild-type strains SF 26 and $74 \mathrm{~A}$ was estimated by assaying the medium and a mycelial extract ( $0.075 \mathrm{M}$-acetate buffer, $\mathrm{pH} 4.2)$ of $76 \mathrm{~h}$-old liquid cultures. The dry weight of the mycelium was determined (Bates, Hedman \& Woodward, 1967) and used as a basis for calculating total invertase activity associated with the mycelium.

Ouchterlony gel diffusion assays. Assays for the detection of cross-reacting material were performed according to the method of Ouchterlony (1949). The medium consisted of I $\mathbf{g}$ Noble agar, $5 \mathrm{ml}$ of $0.05 \mathrm{M}$-phosphate buffer $(\mathrm{pH} 7), \mathrm{r} \mathrm{ml}$ merthiolate (0.1\% solution) and $94 \mathrm{ml}$ water. The medium was poured into $60 \mathrm{~mm}$ Petri plates and a Grafar Auto-Grel punch was used to cut wells in the medium. The invertase antibody was produced by Antibodies, Inc., Davis, California, purified invertase from the L5-D strain of Neurospora crassa 


\title{
Table I. Invertase activity of slime mutant
}

Flasks containing $50 \mathrm{ml}$ of liquid culture were inoculated with equal numbers of cells and incubated for the indicated times. At each test interval, a flask was removed and the entire contents dialysed at $4{ }^{\circ} \mathrm{C}$ against a volume of 21 of water for $48 \mathrm{~h}$, with five or more changes of water. The dialysis residue was assayed for invertase activity and protein.

$\begin{array}{ccc}\text { Time (h) } & \begin{array}{c}\text { Specific } \\ \text { activity }\end{array} & \begin{array}{c}\text { Total activity/ } \\ \text { culture }\end{array} \\ 24 & 0.05 & 3 \\ 36 & 0.12 & 9 \\ 48 & 0.11 & 7 \\ 60 & 0.87 & 75 \\ 72 & 1.87 & 287\end{array}$

Table 2. Invertase secretion by the slime mutant

\begin{abstract}
Cultures were grown at $34^{\circ} \mathrm{C}$ in $50 \mathrm{ml}$ volumes for the indicated time. The amount of cell material present at each age was estimated by determining the absorbance of the culture in a Klett-Summerson colorimeter using a red filter. The cultures were centrifuged and the supernatant fluid was removed for assay as required. The pellet was resuspended in $0.075 \mathrm{M}$-acetate buffer, $\mathrm{pH} 4.2$, and agitated on a shaker at $4{ }^{\circ} \mathrm{C}$ for $\mathrm{I} \mathrm{h}$. The extract was centrifuged and the pellet resuspended in $0.05 \mathrm{M}$-acetate buffer, $\mathrm{pH} 5$, to insure retention of invertase associated with the cell debris. These fractions were then assayed as described in Methods. The first fraction, the medium, contained secreted invertase and the last two fractions contained cell-associated invertase.
\end{abstract}

$\begin{array}{clcc}\begin{array}{c}\text { Time } \\ \text { (h) }\end{array} & \text { Fraction } & \begin{array}{c}\text { Total activity } \\ \text { colorimeter unit }\end{array} & \begin{array}{c}\text { Total } \\ \text { activity } \\ (\%)\end{array} \\ 48 & \text { Secreted } & 0.61 & 96 \\ & \text { Cell associated } & 0.03 & 4 \\ 72 & \text { Secreted } & 0.64 & 97 \\ & \text { Cell associated } & 0.02 & 3 \\ 96 & \text { Secreted } & 2.09 & 97 \\ & \text { Cell associated } & 0.06 & 3\end{array}$

having been used as antigen. The antiserum was placed in the centre well and samples of slime invertase taken from 6o, 72 and $96 \mathrm{~h}$ cultures and of SF 26 purified invertase were placed in side wells. The plates were kept in a humid chamber for 2 to 3 days until precipitin lines formed.

Estimation of cell lysis. Slime cells and SF 26 conidia on slants were suspended in sterile medium and the absorbance at $660 \mathrm{~nm}$ of each suspension was determined. Using extinction as a measure of amount of cells present, equal quantities of cells were added to each flask of medium. The cultures were incubated for 48,60 and $72 \mathrm{~h}$, flasks of slime and sF 26 cultures removed and the contents centrifuged. The optical density of the supernatant fluid was determined at $260 \mathrm{~nm}$. The dry weight of slime cells and SF 26 mycelium was determined at each time sampled and extinction at $260 \mathrm{~nm}$ was calculated on the basis of extinction/g.

\section{RESULTS AND DISCUSSION}

Invertase secretion. Invertase assays of liquid slime cultures at various ages demonstrated that invertase was produced by this mutant. Very low levels of invertase activity (Table I) were present in young cultures from 24 to $48 \mathrm{~h}$. After $48 \mathrm{~h}$, the levels of invertase increased, the amount of invertase present approaching wild-type 74A Neurospora crassa levels of invertase after $60 \mathrm{~h}$. Ouchterlony gel diffusion assays showed that the slime invertase 
cross-reacted with anti-invertase antibody and gave a single line of identity with wild-type invertase. These results indicated that invertase produced by the mutant was very similar, if not identical, to wild-type invertase. Almost all the invertase (about 95\%) produced by the slime mutant is secreted into the media and very low levels are present in the cells (Table 2). In contrast, in wild-type strains only $19.5 \%(74 \mathrm{~A})$ and $\mathrm{I} \cdot 5 \%$ (SF 26) of the total invertase was found in the medium.

What appeared to be actively secreted invertase could actually have been released into the external surroundings by cell lysis. In order to determine whether or not this was probable, slime and SF 26 Neurospora crassa cultures were sampled at 48,72 and $96 \mathrm{~h}$ incubation. The extinction at $260^{\circ} \mathrm{nm} / \mathrm{g}$ of cells $(s l$ or SF 26$)$ did not increase as the cultures aged, indicating that substantial lysis was not occurring.

The distribution of invertase between cell and external milieu in slime cultures resembled the distribution found in artificially produced protoplasts. Trevithick \& Metzenberg (1964) reported that invertase was secreted by Neurospora crassa protoplasts at a linear rate over $\mathrm{I} 8 \mathrm{~h}$ of incubation. Invertase within protoplasts remained constant for $\mathrm{I} 2 \mathrm{~h}$ and then increased slightly by $\mathrm{I} 8 \mathrm{~h}$ of incubation. They attributed the increase to partial regeneration of cell wall. Even with this increase, an examination of their data showed that at $\mathrm{I} 8 \mathrm{~h} 80 \%$ or more of the total invertase was found in the external menstruum.

Ultrastructure. Thin sections of slime cells from solid and liquid media showed no wall at any stage. The cells were bounded by a unit membrane with a total thickness of approximately $9 \mathrm{~nm}$ (Fig. 2, 3, 4, 5) which was frequently convoluted and appeared at times to form invaginated pockets.

All cells were multinucleate and the nucleus was surrounded by a typical double membrane (Fig. 4). The nucleus frequently contained a denser granular area which was probably the nucleolus (Fig. 4). Little endoplasmic reticulum was present (Fig. 5). Oval and spherical membrane-bounded bodies ranging in diameter from $0.15 \mu \mathrm{m}$ to $0.3 \mu \mathrm{m}$ were often found (Fig. 3, 4, 5); they are presumed to be lipid globules. None of the cells possessed Golgi or dictyosomes. Glycogen granules were not found.

Other morphological features varied with cell age or type of substrate (solid or liquid). The majority of the cells from liquid culture were spherical or oval but cells grown on solid surfaces were pleomorphic and had projections (Fig. 3). The size of cells growing on solid medium increased with time, having at $48 \mathrm{~h}$ an average diameter of $6 \mu \mathrm{m}$ and at $72 \mathrm{~h}$ an average diameter of $10 \mu \mathrm{m}$ (Fig. 3). The size of cells growing in liquid media decreased with time, at $48 \mathrm{~h}$ being $10 \mu \mathrm{m}$ (Fig. 4), and at $96 \mathrm{~h} 3 \mu \mathrm{m}$ (Fig. 2)

The mitochondria of young slime cells in liquid culture resembled those of wild-type Neurospora crassa (Fig. I, 4). The cristae were distinct and were arranged randomly with respect to the longitudinal axis of the mitochondria. In older cells (Fig. 2, 3, 5) the mitochondria did not resemble those of wild-type cells, being more electron dense and with cristae ill defined. Intracristal.spaces seemed to be lacking. This appearance might have been caused by such factors as dilation of intracristal spaces and accumulation of materials with affinity

Fig. I to 5. er, endoplasmic reticulum; $c w$, cell wall; $p m$, plasma membrane; $m$, mitochondria; $b$, lipid globules; $n$, nucleus; $v$, vacuole. All scale markers represent $\mathrm{I} \mu \mathrm{m}$.

Fig. I. Wild-type Neurospora crassa mycelium, showing layered cell wall and typical mitochondria.

Fig. 2. Neurospora crassa slime cell from a 96 h-liquid culture, illustrating vacuoles, electron-dense mitochondria and absence of cell wall.

Fig. 3. Neurospora crassa slime cell from agar after $72 \mathrm{~h}$, showing vacuoles, endoplasmic reticulum, electron-dense mitochondria and pleomorphic nature. 

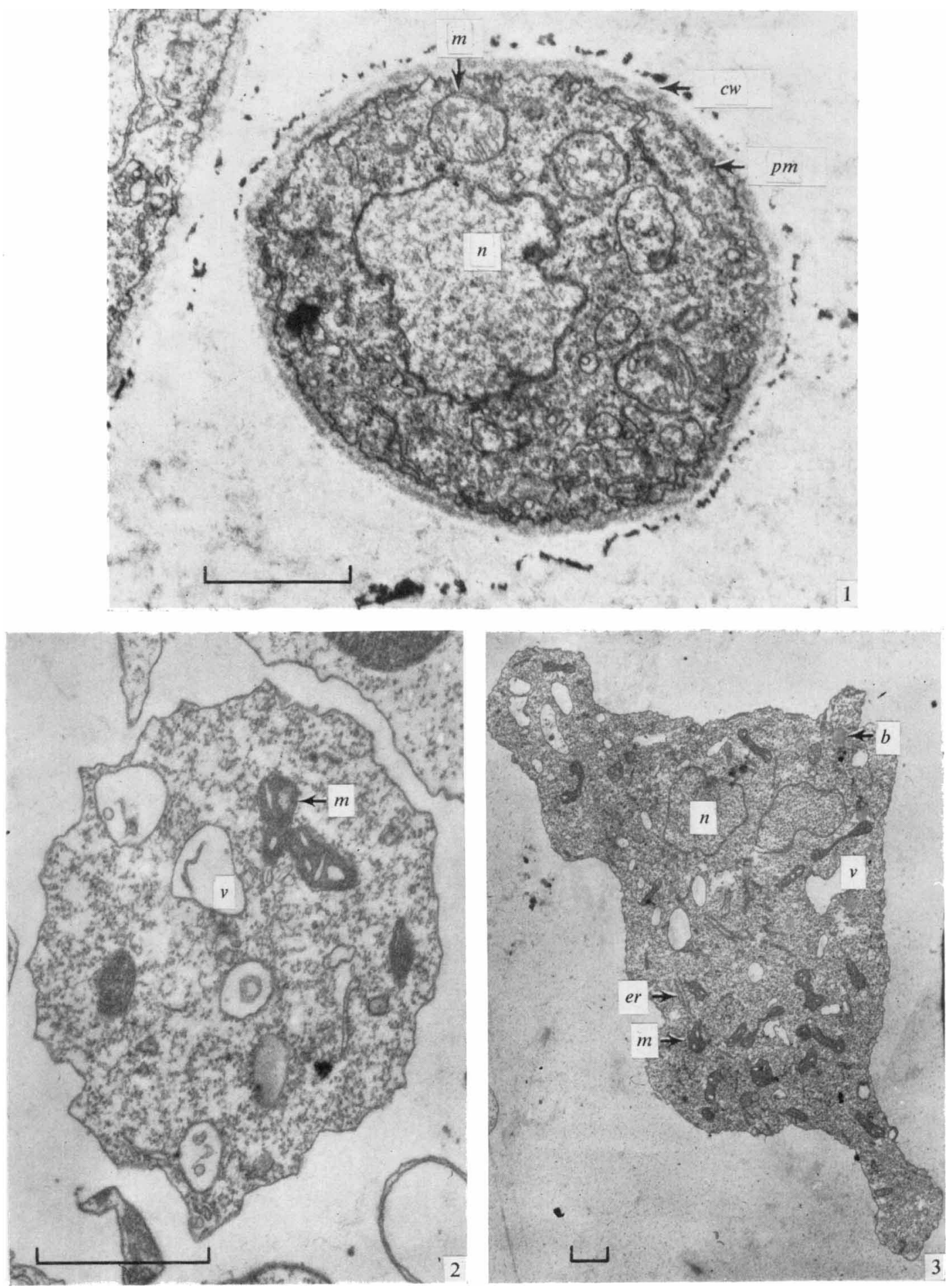

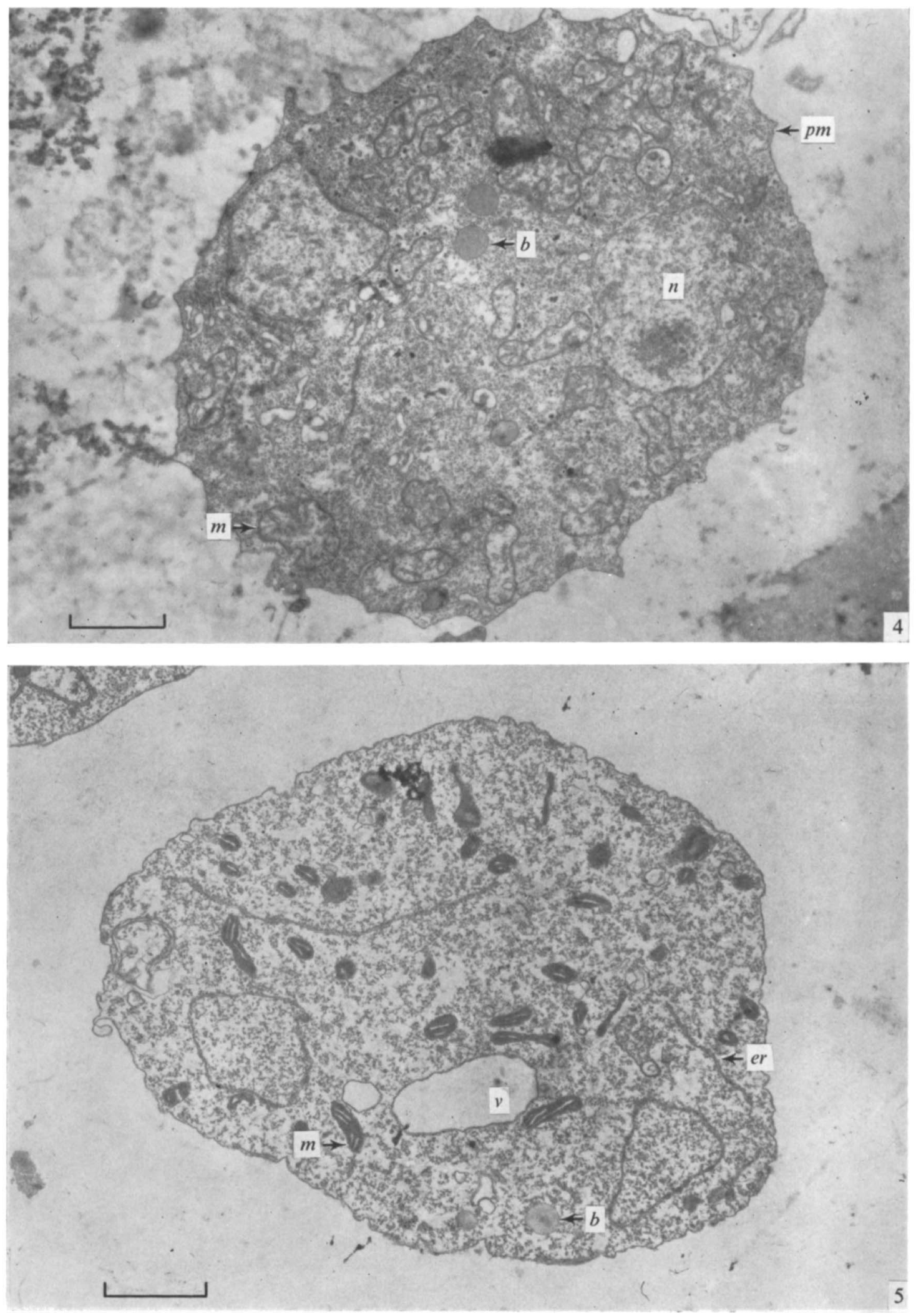
for the stains used. Great variation in the shape of mitochondria was found. They were spherical, oval, elongated or irregular and some were branched, with width ranging from $0.07 \mu \mathrm{m}$ to $0.83 \mu \mathrm{m}$, length of elongated forms from $0.45 \mu \mathrm{m}$ to $2 \mu \mathrm{m}$. Cross sections of older cells in liquid culture contained very few mitochondria, nine being the maximum found in any one section and many containing less than five. Large numbers of mitochondria (20 to 90 per section) were found in young cells growing on solid medium. Older cells from solid media and younger cells from liquid media contained more nuclei ( $\mathrm{I}$ to 6 per cross section) than younger cells from solid media and older cells from liquid media (I to 2 per section). Some nuclei were spherical or oval in shape but most were irregular. We did not find any correlation between age or size of these cells and the shape of the nucleus, which might have indicated whether or not nuclear division was occurring (Namboodiri, 1966). Cells grown on solid media contained vacuoles of moderate size (Fig. 3). Young cells from liquid culture did not contain vacuoles (Fig. 4), but older cells were highly vacuolated (Fig. 2).

The ultrastructure of the slime mutant resembles that of protoplasts (Bachmann \& Bonner, 1959; Manocha, 1968). The mutant cells contained numerous vesicles, vacuoles and mitochondria but little endoplasmic reticulum. The nuclei resembled those of protoplasts and the cells were approximately the same size as protoplasts. The most obvious common feature between the slime cells and protoplasts is the lack of a wall, evident when the outer boundary of the slime variant (Fig. 2, 3, 4, 5) is contrasted with that of wild-type Neurospora crassa (Fig. I). The wild-type wall consisted of the two layers described by Shatkin \& Tatum (1959). The outer electron-dense layer appeared to be frayed; the inner layer was broader and electron transparent. The slime mutant lacked the two wall layers and was bounded only by a unit membrane of $9 \mathrm{~nm}$ thickness. This corresponds closely to the width of $7 \mathrm{~nm}$ reported for the plasma membrane of wild-type N. crassa (Shatkin \& Tatum, 1959) and of $8 \mathrm{~nm}$ reported for that of yeast protoplasts (Hirano, Tacreiter, Eaves \& Kaplan, I968).

Other workers have reported the presence of a continuous abnormal cell wall on slime sphaeroplasts (Emerson, I963) or a discontinuous one on slime hyphlets (Woodward \& Woodward, I968; van Winkle, 1969). We examined thin sections of the cells which were used to inoculate liquid cultures, and cells produced in liquid culture through 4 days of incubation and found no wall material at any stage. The difference in our findings and those of others may be due to the fact that we studied only $s l$ strain no. II 8 , whereas others studied, in addition or exclusively, $s l$ strain no. 327. We feel that the slime mutant cells we examined would more aptly be referred to as 'protoplasts' rather than sphaeroplasts or hyphlets, as the mutant cells mimicked artificially produced protoplasts of Neurospora crassa. However, the slime cells had the advantage of being stable 'protoplasts' and did not regenerate cell wall, so they should serve as an excellent system for studying enzyme secretion and other phenomena related to the two outer boundaries of the cell, the plasma membrane and the wall.

The authors are indebted to Dr M. D. Socolofsky for technical assistance and criticism and for his generous loan of equipment and materials for electron microscopy, Dr H. J. Werner for excellent advice and criticism, Dr A. D. Larson, and Mrs S. B. Templet for

Fig. 4. Neurospora crassa slime cell from a 48-h liquid culture, illustrating typical mitochondria found in younger slime cultures.

Fig. 5. Neurospora crassa slime cell from agar aiter $72 \mathrm{~h}$., showing electron-dense and abnormallyshaped mitochondria. 
helpful suggestions in writing this manuscript and assistance with photography. One of the authors (CHB) was supported by a National Science Foundation Traineeship. This research was supported in part by a grant from the National Science Foundation (no. GB 6382).

\section{REFERENCES}

BACHMANN, B. J. \& BonNeR, D. M. (1959). Protoplasts from Neurospora crassa. Journal of Bacteriology 78 , $550-556$.

Bates, W. K., Hedman, S. C. \& Woodward, D. O. (1967). Comparative inductive responses of two $\beta$ galactosidases of Neurospora. Journal of Bacteriology 93, I63I-I637.

ChUNG, P. Y. \& TREVITHICK, J. R. (1970). Biochemical and histochemical localization of invertase in Neurospora crassa during conidial germination and hyphal growth. Journal of Bacteriology 102, 423-429.

EMERSON, S. (1963). Slime, a plasmodioid variant of Neurospora crassa. Genetica 34, I62-I82.

GratzNER, H. \& Sheehan, D. N. (1969). Neurospora mutant exhibiting hyperproduction of amylase and invertase. Journal of Bacteriology 97, 544-549.

Hirano, T., TACreiter, W., Eaves, A. \& Kaplan, J. G. (I968). The plasma membrane of yeast protoplasts. Cytologia 33, 558-564.

Lowry, O. H., Rosebrough, N. J., Farr, A. L. \& Randall, R. J. (I95I). Protein measurement with the Folin phenol reagent. Journal of Biological Chemistry 193, 265-275.

MANOCHA, M. S. (1968). Electron microscopy of the conidial protoplasts of Neurospora crassa. Canadian Journal of Botany 46, $156 \mathrm{I}-1564$.

MANOCHA, M. S. \& Colvin, J. R. (1967). Structure and composition of the cell wall of Neurospora crassa. Journal of Bacteriology 94, 202-2 2.

Meachum, Z. D. \& Braymer, H. D. (1969). Localization of invertase in the cell wall of Neurospora crassa. Proceedings of the 158 th National Meeting of the American Chemical Society, Abstract no. 195.

Meachum, Z. D., Colvin, H. J. \& Braymer, H. D. (1971). Chemical and physical studies of Neurospora crassa invertase; molecular weight, amino acid and carbohydrate composition and quaternary structure. Biochemistry xo, 326-332.

MetZenBeRG, R. L. (1962). A gene affecting the repression of invertase and trehalase in Neurospora. Archives of Biochemistry and Biophysics 96, 468-474.

MetzenBerg, R. L. (1963). The localization of $\beta$-fructofuranosidase in Neurospora. Biochimica et biophysica acta 77, 455-465.

NAMBoodiRI, A. N. (1966). Electron microscopic studies on the conidia and hyphae of Neurospora crassa. Caryologia 19, I17-132.

OUCHTERLONY, O. (1949). Antigen-antibody reactions in gels. Acta pathologica et microbiologica scandinavica 26, 507-513.

REYNOLDS, E. S. (1963). The use of lead citrate at high $\mathrm{pH}$ as an electron-opaque stain in electron microscopy. Journal of Cell Biology 17, 208-213.

SARGENT, M. L. \& WoOdWARD, D. O. (I969). Gene-enzyme relationships in Neurospora invertase. Journal of Bacteriology 97, 867-872.

Shatkin, A. J. \& TAtum, E. L. (1959). Electron microscopy of Neurospora crassa mycelia. Journal of Biophysical and Biochemical Cytology 6, 423-426.

Trevithick, J. R. \& MetzenBerg, R. L. (1964). The invertase isozyme formed by Neurospora protoplasts. Biochemical and Biophysical Research Communications 16, 319-325.

Trevithick, J. R. \& Metzenberg, R. L. (1966). Molecular sieving by Neurospora cell walls during secretion of invertase isozymes. Journal of Bacteriology 92, 1010-1015.

Voges, H. J. (1964). Distribution of lysine pathways among fungi; evolutionary implications. American Naturalist 98, 435-436.

VAN WINCKLE, W. B. (1969). Preliminary observations of the ultrastructure of the slime mutant. Neurospora Newsletter 14, 5.

WoodWard, V. W. \& WoodWard, C. K. (1968). The care and feeding of slime. Neurospora Newsletter r3, 18. 